\title{
Contribution of Peroxynitrite, a Reactive Nitrogen Species, in the Pathogenesis of Autoimmunity
}

\author{
Rizwan Ahmad ${ }^{1}$ and Haseeb Ahsan ${ }^{2}$ \\ ${ }^{1}$ Department of Biochemistry, Oman Medical College, Sohar, \\ ${ }^{3}$ Department of Biochemistry, Faculty of Dentistry, Jamia Millia Islamia, New Delhi, \\ ${ }^{1}$ Sultanate of Oman \\ India
}

\section{Introduction}

Peroxynitrite is a member of reactive nitrogen species that also includes nitric oxide ( $\mathrm{NO})$ and nitrogen dioxide radical $\left(\mathrm{NO}_{2}\right)$. Peroxynitrite is a reactive nitrogen species and an anion with the formula $\left(\mathrm{ONOO}^{-}\right)$. It is an unstable 'valence isomer' of nitrate $\left(\mathrm{NO}_{3}{ }^{-}\right)$, making it an oxidant and nitrating agent. Because of its oxidizing properties, peroxynitrite can damage a wide range of molecules in cells, including DNA and proteins (1). It is produced by the body in response to a variety of environmental toxins, stress, ultraviolet light and many other stimuli. It is also produced in the body due to ischemia/ reperfusion injury and inflammation $(2,3)$. In vivo, peroxynitrite is formed in the macrophages, endothelial cells, platelets, leukocytes, neurons, etc by the reaction between $\mathrm{O}_{2} \cdot-$ and $\mathrm{NO}(4,5)$. Tissue inflammation and chronic infection lead to the overproduction of $\mathrm{NO}$ and $\mathrm{O}_{2}-$, which rapidly combine to yield peroxynitrite: $\mathrm{O}_{2}{ }^{-\cdot}+\mathrm{NO} \rightarrow \mathrm{ONO}_{2}{ }^{-}$. Endothelial $\mathrm{NO}$ synthase (eNOS) is responsible for most of the vascular $\mathrm{NO}$ produced. The eNOS oxidizes its substrate L-arginine to L-citrulline and NO. A functional eNOS requires dimerization of the enzyme, the substrate L-arginine, and an essential cofactor, BH4 (5,6,7,8-tetrahydro-Lbiopterin). The $\mathrm{O}_{2} \cdot$ - produced can react with vascular $\mathrm{NO}$ to form peroxynitrite. Diminished levels of $\mathrm{BH} 4$ promote $\mathrm{O}_{2} \cdot$ - production by eNOS. The transformation of eNOS from a vasoprotective enzyme to a contributor to oxidative stress has been observed in several in vitro systems, animal models of cardiovascular diseases and in patients with cardiovascular risk factors (6). In inflammation or septic shock, NO is also synthesized by the inducible $\mathrm{NO}$ synthase (iNOS), an isoform that is expressed in many cell types including vascular endothelial cells, vascular smooth muscle and inflammatory cells in response to pro-inflammatory cytokines. Peroxynitrite, can be formed intravascularly in various disease conditions when there is overproduction of either $\mathrm{NO}$ or $\mathrm{O}_{2} \cdot{ }^{-}(7)$. The intravascular formation of peroxynitrite can result in oxidative modifications of plasma and vessel wall proteins including the formation of protein-3-nitrotyrosine. Protein tyrosine nitration in plasma or vessel wall proteins may be indicative of peroxynitrite formation, and constitutes a good biomarker of NO-derived oxidant production in the vascular space. Detection of 3-nitrotyrosine in vivo has attracted considerable interest not only as a biomarker of peroxynitrite formation but also as a predictor of vascular risk (8). 
Peroxynitrite is a potent oxidant and nitrating species formed by rapid reaction of two free radicals - nitric oxide and superoxide anion (9). It can modify variety of biomolecules but possesses high affinity for tyrosine residues in proteins, and 3-nitrotyrosine is a relatively specific marker of peroxynitrite mediated damage to proteins (10). Other markers of peroxynitrite-induced protein modifications are; cysteine oxidation, oxidation/nitration of tryptophan and tyrosine, protein carbonyls, dityrosine and fragmentation. In view of numerous reports on detection of significant amount of 3-nitrotyrosine in various pathological conditions, the significance of non-enzymatic tyrosine nitration in health and disease has become a subject of great interest. Protein nitration has been observed in atherosclerosis, hypertension, Parkinson's, Huntington's and Alzheimer's disease (11-13), multiple sclerosis (14), autoimmune myocarditis (15), systemic lupus erythematosus (SLE) (16) and rheumatoid arthritis (17). Furthermore, self proteins become immunologically active if their structure is altered. Accumulations of a variety of chemically modified proteins have been reported in inflamed tissues or apoptotic cells (18).

Histones are highly conserved proteins but poorly immunogenic. These positively charged proteins were found to be immunogenic after acetylation or complexation with RNA. Autoantibodies against histones are present as often as anti-DNA antibodies in SLE. It has been demonstrated that anti-native DNA autoantibodies are commonly co-present with anti-histone autoantibodies and may react with each of the five chromatin-associated histones and also with H3-H4 and H2A-H2B complex (19). However, importance of antihistone antibodies in SLE is confounded by discrepancies in their reported prevalence, isotype, specificity and correlation with symptoms. Over expression of inducible nitric oxide synthase enzyme has been seen in numerous tissues of active SLE patients, vis-à-vis higher level of serum nitrotyrosine. Nitrotyrosine serves as a long-term indicator of peroxynitritemediated protein modification and it is not affected by endogenous source of NOx or serum thiol (20). The in vivo nitration of histones (as shown in cultured cells exposed to nitric oxide donors and mutatect tumour tissues) appears to be a potentially useful marker for demonstrating extended exposure of cells/tissues to NO derived reactive nitrogen species. The generation of peroxynitrite by activated macrophages, neutrophils and endothelial cells and presence of nitrotyrosine in human tissues, fluids and in animal models of various diseases needs further investigation on protein-peroxynitrite interactions (21).

\section{Cellular biochemistry and pathology}

Peroxynitrite is a relatively long-lived oxidant that may serve as an important cytotoxic agent. Its biological effects are due to its reactivity toward a large number of molecules including lipids, amino acids, and nucleic acids. It is involved in tissue damage in a number of pathophysiological conditions such as neurodegenerative diseases, cardiovascular disorders, etc. (1-3). Evidence suggests that most of the cytotoxicity attributed to nitric oxide is due to peroxynitrite, produced from the reaction between the free radical species, $\mathrm{NO}$ and $\mathrm{O}_{2} \cdot{ }^{-}$. Peroxynitrite interacts with lipids, DNA and proteins causing oxidative damage and other free radical induced chain reactions. These reactions trigger cellular responses such as cell signaling, oxidative injury, committing cells to necrosis or apoptosis. In vivo, peroxynitrite generation represents a crucial pathological mechanism in conditions such as stroke, myocardial infarction, chronic heart failure, diabetes, inflammation, neurodegenerative disorders and cancer. Even though nucleic acid antigens are by themselves poorly immunogenic, their antigenicity can be enhanced by modification through different free radicals (8). 
Peroxynitrite exhibits unique chemical reactivities such as protein nitration, DNA strand breakage, base modification, etc., which may have cytotoxic effects and also lead to mutagenesis. It is thought to be involved in both cell death and an increased cancer risk (822,23 ). The reaction of peroxynitrite with lipids leads to peroxidation (malondialdehyde and conjugated diene formation) and formation of nitrito-, nitro-, nitrosoperoxo-, and nitrated lipid oxidation derivatives (24-26). Peroxynitrite is a particularly effective oxidant of aromatic molecules, thioethers and organosulfur compounds that include free amino acids and polypeptide residues.

The reaction of various amino acids with peroxynitrite leads to the following products: 1 ) cysteine and glutathione are converted to disulfides; 2 ) methionine is converted to sulfoxide or is fragmented to ethylene and dimethyl disulfides. Dimethyl sulfoxide is oxidized to formaldehyde; and 3) tyrosine and tryptophan undergo one electron oxidation to radical cations, which are hydroxylated, nitrated and dimerized (27-29). Exposure of amino acids, peptides and proteins to ionizing radiation such as gamma radiation and peroxynitrite in the presence of $\mathrm{O}_{2}$, give rise to hydroperoxides. These hydroperoxides decompose to oxygen and carbon centered radicals on exposure to copper $(\mathrm{Cu}+)$ and other transition metal ions. Hydroperoxide formation on nuclear proteins results in oxidative damage to associated DNA. These hydroperoxide-derived radicals react readily with pyrimidine DNA bases and nucleosides to form adduct species, for example 8-oxo-dG. This adduct is highly mutagenic and induces G:C to T:A transversions in human DNA after replication (30).

A change in the structure of DNA could either be due to radiation or due to interaction with different free radicals (31). Since there are many polybasic compounds in the vicinity of DNA, there exists a possibility of their interaction with DNA on exposure to radiation or free radicals. Lysine and arginine-rich histones in nucleosomes on modification by environmental agents form histone-DNA adducts, making it immunogenic. It appears that the pathogenic anti-DNA autoantibodies are generated through some modified epitopes on nucleic acids (32-34). Prominent DNA modifications induced by exposure to peroxynitrite include the formation of 8-nitro-guanine and 8-oxyguanine, as well as the induction of single-strand breaks (35). Peroxynitrite reacts significantly only with guanine, which upon oxidation and nitration leads to mutagenicity and strand breaks, respectively. Peroxynitrite also damages DNA by covalent bond formation and removal of DNA bases (36).

Purine nucleotides are vulnerable to oxidation and to adduct formation $(37,38)$. Peroxynitrite is a mutagenic agent with a potential to produce nitration, nitrosation and deamination of DNA bases. Methylation of cytosine in DNA is important for the regulation of gene expression and normal methylation patterns are altered by the carcinogenic effect of peroxynitrite (39). Prominent DNA modifications induced by peroxynitrite include the formation of 8-nitro-guanine and 8-oxyguanine, as well as the induction of single strand breaks (40). DNA single strand breaks generated by peroxynitrite leads to activation of the nuclear enzyme, poly (ADP-ribose) synthetase (PARS), which can trigger cellular suicidal pathway. Single strand breaks generated by peroxynitrite can arise from two processes: 1) sugar damage, which involves abstraction of hydrogen leading to the formation of sugar radical or 2) base damage, which rapidly depurinates to generate abasic sites, finally resulting in single strand breaks (41). Peroxynitrite is mutagenic in the supF gene inducing $G$ to $\mathrm{T}$ transversions and deletions clustered at the $5^{\prime}$ end of the gene. The mutagenicity of peroxynitrite is believed to result from chemical modifications at guanine leading to miscoding (42). Carcinogenesis is induced by altered DNA or tissue damage, mutations and chromosomal aberrations $(43,44)$. Peroxynitrite is a mutagenic agent with the potential to 
produce nitration, nitrosation and deamination reactions on DNA bases. It reacts significantly only with guanine, which upon oxidation and nitration leads to mutagenicity and strand breaks, respectively $(45,46)$. Peroxynitrite levels are elevated in inflammation and infection and play an important role in autoimmunity and carcinogenesis (Figure 1). It damages tumor suppressor genes and leads to the expression of proto-oncogenes. Peroxynitrite induced DNA damage leading to mutations has been strongly implicated in carcinogenesis (47) (Figure 1).

\section{DNA}

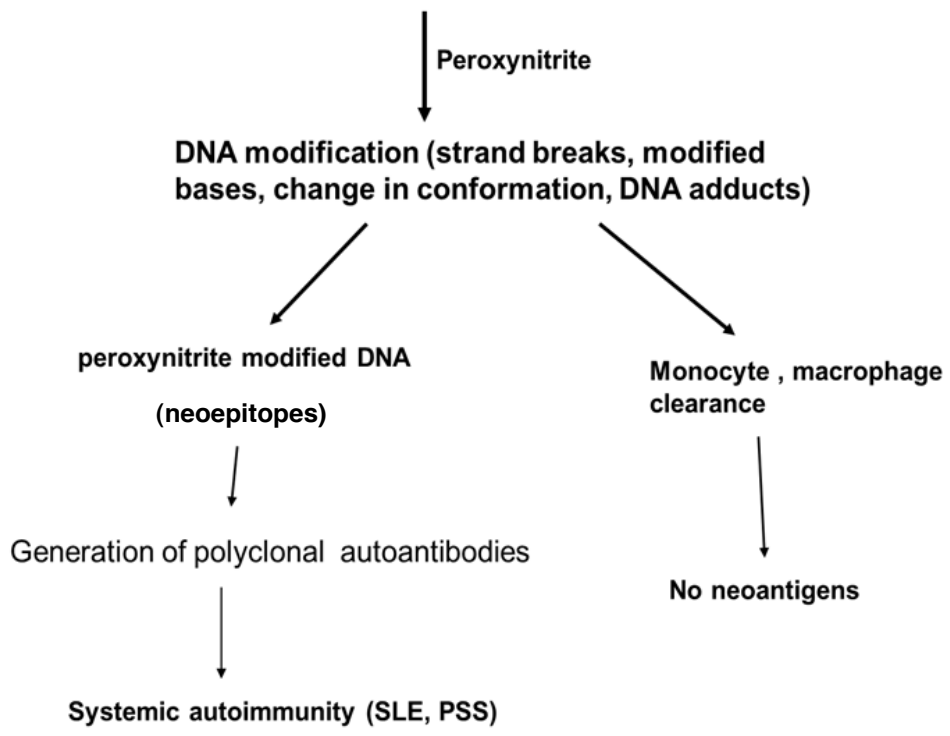

Fig. 1. The role of peroxynitrite, a reactive nitrogen species, in the etiopathogenesis of autoimmune disorders, such as systemic lupus erythematosus (SLE) and progressive systemic sclerosis (PSS).

Proteins are targets of reactive nitrogen species such as peroxynitrite and $\mathrm{NO}_{2}$. Among the various amino acids in proteins, tryptophan residues are especially susceptible to attack by reactive nitrogen species (48). Peroxynitrite is capable of oxidizing protein and non-protein sulfhydryl $(-\mathrm{SH})$ groups including lipid peroxidation and reactivity with aromatic amino acid side chain in proteins to form nitroadducts (49). Peroxynitrite induced tyrosine nitration may lead to dysfunction of nitrated proteins, SOD, cytoskeletal proteins, neuronal tyrosine hydroxylase, cytochrome P450 and prostacyclin synthase (50-53). Oxidation of critical -SH groups is responsible for the inhibition of mitochondrial and cytosolic aconitase and other critical enzymes in the mitochondrial respiratory chain (54). Peroxynitrite mediated nitration of myofibrillar creatine kinase activity may lead to contractile dysfunction of the heart (55). Peroxynitrite-modified cellular proteins are subject to accelerated degradation via the proteosome (56).

Adducts arise from the chemical modification of bases in DNA or amino acids in proteins by toxic chemicals and high energy UV radiation. Many chemicals known to be carcinogenic in 
humans have been shown to form adducts. Ultraviolet radiation is regarded as one of the major environmental factors responsible for the photoconjugation of DNA with amino acid residues. Lysine is an amino acid of particular interest as a potential participant in DNAprotein photo-cross-linking. Nearly $60 \%$ of thymine and cytosine bases in DNA are modified due to lysine photoaddition and approximately every helical turn of DNA contains one lysine molecule in the photobound state (57). It appears to enhance the antigenicity of the DNAlysine adduct, suggesting possible roles of peroxynitrite-induced neoepitopes in damaged DNA in the production of autoantibodies in cancer patients (58).

Ahmad et al have characterised the peroxynitrite treated human-DNA lysine photoadduct (59). We have investigated the photochemical addition of lysine to native DNA in view of its potential importance in the photo-cross-linking of histones to DNA in chromatin. The C-2 carbon atom of thymine in DNA undergoes a covalent photoaddition reaction with the $\varepsilon^{-}$ amino group of lysine on UV irradiation to form a DNA-lysine photoconjugate or photoadduct (57). The UV spectroscopic analysis of the DNA-lysine photoadduct showed hyperchromism, indicating either the formation of single-stranded breaks in DNA or "breathing" of a double-stranded polymer at the site of lysine conjugation. Peroxynitrite caused substantial damage to the DNA-lysine adduct as evident from the hyperchromicity of the spectral curve, which could be attributed to the generation of strand breaks (Figure 2A). On peroxynitrite modification, the hypochromicity increased, which may be due to the shielding effect of lysine, limiting the sites for peroxynitrite action. Hypochromicity may also be attributed to the extensive cross-linking between peroxynitrite and the DNA-lysine adduct (31).

As shown in Figure 2B, the fluorescence emission intensity (FI) was highest for native DNA (curve 1) and least for the DNA-lysine photoadduct (curve 3). However, on peroxynitrite modification there was a change in the emission intensity, as seen in the figure (curve 2). A decrease in FI of $45.2 \%$ for the DNA-lysine photoadduct in comparison to the peroxynitritemodified DNA-lysine adduct was observed from fluorescence spectroscopy measurements. Loss of FI of $21.3 \%$ in the peroxynitrite-modified adduct with respect to native DNA is indicative of the loss of structural integrity in DNA and generation of single-strand regions (59). The UV absorption and fluorescence characteristics of native and modified lysine photoadduct have been summarized in Table 1.

\begin{tabular}{|l|l|l|l|}
\hline Properties & Native DNA & Native adduct & Modified adduct \\
\hline A260/280 ratio & 1.74 & 1.20 & 1.01 \\
\hline $\begin{array}{l}\text { Melting temperature } \\
\left({ }^{\circ}\right)\end{array}$ & 75 & 70 & 85 \\
\hline Hyperchromicity $(\%)$ & - & 52 & 84 \\
\hline Loss of FI (\%) & - & 76.1 & 21.3 \\
\hline
\end{tabular}

Table 1. Absorption and fluorescence characteristics of native DNA, DNA-lysine photoadduct (native adduct) and peroxynitrite-modified photoadduct (modified adduct) 


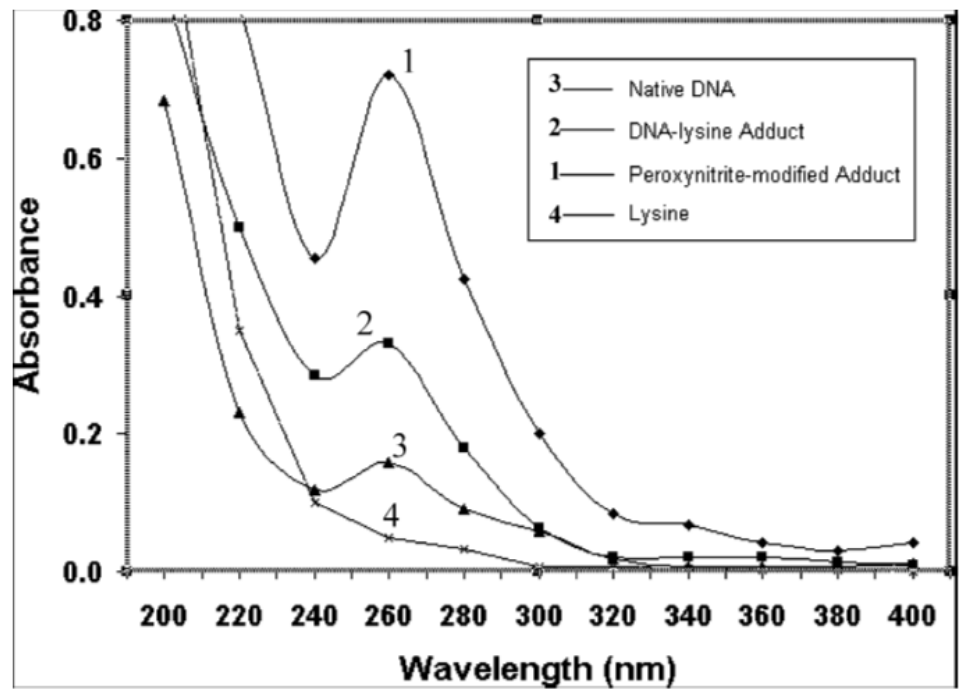

(a)

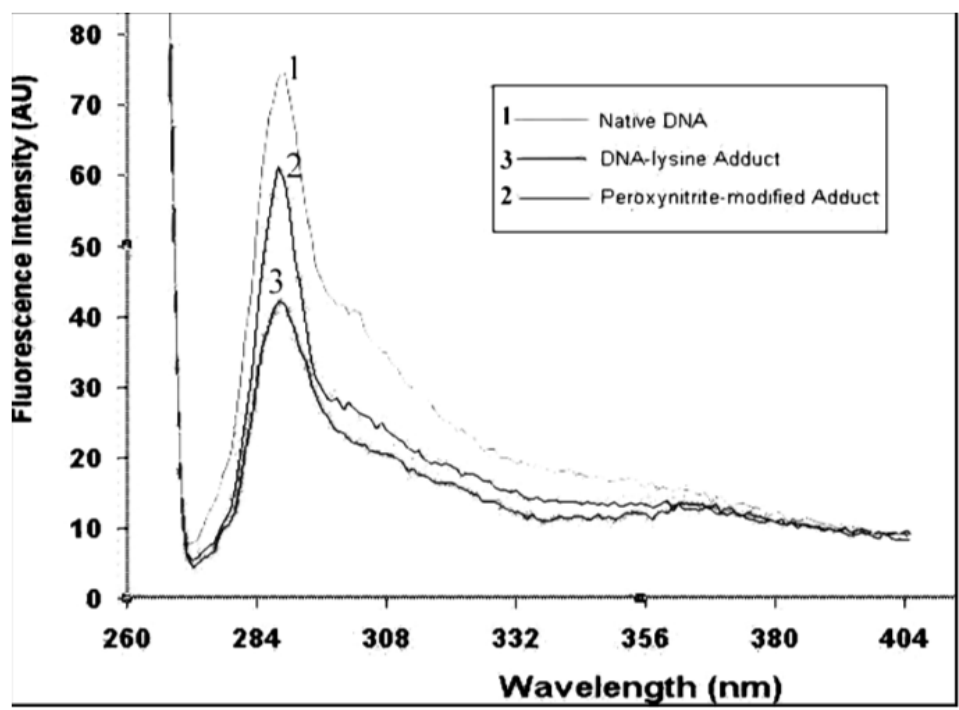

(b)

Fig. 2. UV absorption spectra of native DNA (curve 3), DNA-lysine photoadduct (curve 2) and peroxynitrite-modified adduct (curve 1). 2B: Fluorescence spectra of native DNA (curve 1), DNA-lysine photoadduct (curve 3), and peroxynitrite-modified adduct (curve 2).

The melting profile of the DNA-lysine photoadduct reveals that the ultraviolet radiation induced covalent incorporation of lysine into the native DNA. The photoaddition of lysine to DNA might have obliterated the favorable $A=T$ and $G=C$ pairing interaction of double helical native DNA (57), thus decreasing the duplex melting temperature (Tm) by $5^{\circ} \mathrm{C}$ 
relative to the fully paired parent native DNA. In the study, on peroxynitrite treatment, the $\mathrm{Tm}$ of the DNA-lysine adduct increased by $15^{\circ} \mathrm{C}$ with respect to the native DNA-lysine photoadduct (Figure 3). This may be due to shielding of the available sites for peroxynitrite action by lysine. Hence, more energy would be needed to break the covalent bonding between lysine and the DNA bases in order to denature the double helix (59).

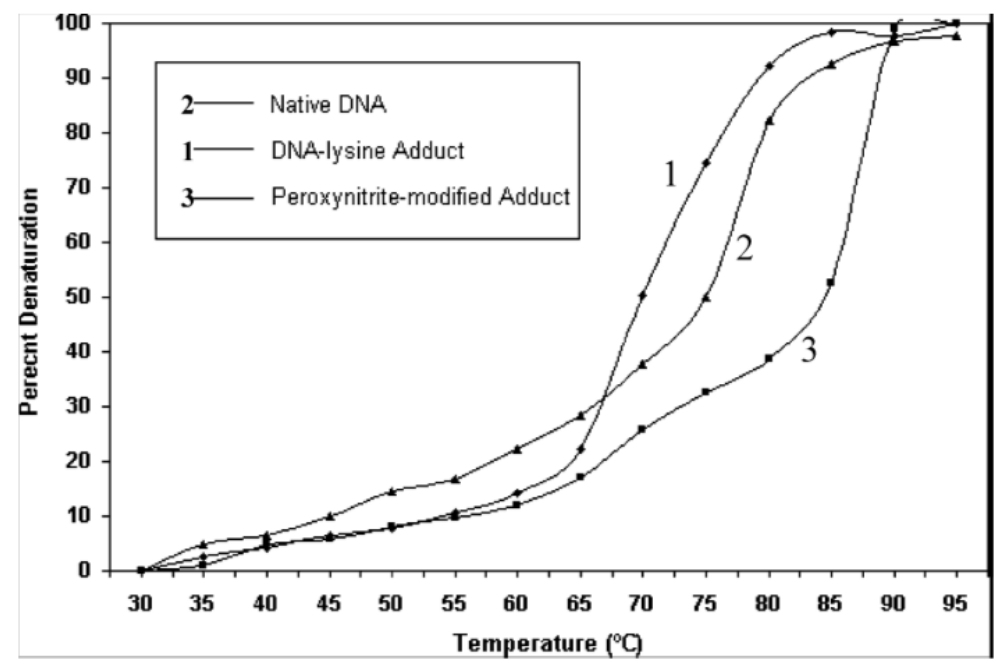

Fig. 3. Thermal melting profile of native DNA (curve 2), DNA-lysine photoadduct (curve 1), and peroxynitrite-modified photoadduct (curve 3).

Biological significance of tyrosine nitration has generated much interest among biomedical scientists because abnormal generation of 3-nitrotyrosine in vivo in diverse pathological conditions have been proved without doubt. Peroxynitrite is a strong oxidant that can oxidize a variety of biomolecules including proteins and non-protein thiol, protein sulphides, lipids and deoxyribose. The markers of oxidative damage to proteins include mainly carbonyls of lysine, arginine, threonine and proline, oxidized tryptophan, tyrosine and cysteine residues and fragmented protein. One persistent footprint left by peroxynitrite is nitration of phenolic ring of tyrosine residues in protein. The resultant 3-nitrotyrosine is a relatively specific marker of nitrosative stress. A recent study on repair of protein nitration in rat tissues by 3-nitrotyrosine denitrase activity suggests that a tyrosine nitrationdenitration pathway participates in nitric oxide/peroxynitrite dependent signal transduction, a phenomenon similar to phosphorylation-dephosphorylation system. The reports suggest that 3-nitrotyrosine has importance not only as biomarker of nitrogen mediated tissue injury but also as a means to gain insight into molecular mechanisms of nitric oxide related physiological and pathophysiological phenomena. Furthermore, hypernitrotyrosinemia has also been reported in various inflammatory diseases including SLE, Sjogren's syndrome, vasculitis and rheumatoid arthritis (60).

Alteration of DNA or proteins resulting from photomodification or peroxynitrite could lead to the development of antibodies or mutations to modified DNA. Therefore, the DNA-lysine photoadduct and modified photoadduct could have important implications in various pathophysiological conditions such as toxicology, carcinogenesis, and autoimmune phenomena (57). 


\section{Autoimmune phenomenon}

Manifestations of autoimmunity are often complex and heterogenous. It has been postulated that the immune response against host antigens could be due to genetic predisposition, exaggerated B cell activity, cross-reactivity between foreign and host antigens, etc. The foreign antigens arise as a consequence of infection, inflammation, drug administration, environmental factors, free radicals, etc $(57,61)$. It has been established that not only oxygen but nitrogen free radicals play an important role in the pathogenesis of several human diseases. Reactive nitrogen species is produced by the reaction of nitric oxide with superoxide. Nitric oxide radical participate in some pathological conditions such as arthritis, vasculitis, asthma, hypertension, etc. It is also an unstable molecule like oxygen free radical but less reactive and can react with proteins (31).

Two diseases that are considered as a prototype for systemic autoimmunity are systemic lupus erythematosus (SLE) and rheumatoid arthritis (RA). SLE is a multi-systemic disorder characterized by a variety of autoantibodies and abnormal lymphocyte function that are responsible for many of the clinical manifestations important in diagnosis. A hallmark of SLE is the presence of antinuclear antibodies (ANA). ANA are prototype autoantibodies that mark the course of rheumatic diseases (62). Because of the close association between ANA and clinical diagnosis, these antibodies have become a key component in the evaluation of patients. These antibodies target a diverse range of macromolecules including DNA, RNA, proteins and protein-nucleic acid (PNA) complexes. Antibodies to DNA have been particularly associated with SLE which is considered to be a prototype autoimmune disease. Native DNA is no longer regarded as the antigen initiating the disease mainly immunization with nDNA does not produce SLE like symptoms. A few of the possible candidates could be polynucleotides, denatured DNA, RNA or modified DNA. While antibodies to single stranded DNA are formed in several inflammatory complexes including RA; antibodies to double stranded DNA serve as an immunochemical marker in the diagnosis of SLE (63). Serum obtained form SLE individuals have been shown to possess anti-DNA antibodies of diverse antigenic specificity. These anti-DNA autoantibodies have been used to evaluate therapeutic effect and clinical features of SLE patients $(64,65)$.

The origin of autoantibody remains an enigma and the production of anti-DNA antibodies is even more complicated. Even though nucleic acid antigens are themselves poorly immunogenic, their antigenicity can be enhanced by modification with agents such as free radicals. Autoantibodies produced against such modified macromolecule are the hallmark of systemic human disease, SLE. B cell hyperactivity and the production of pathogenic autoantibodies is the main immunonological event in the pathogenesis of this disease. One approach to study the pathogenesis of SLE and determine how the autoantibody response is initiated and sustained is to analyse variable genes expressed by antibodies. Quantification of this repertoire has revealed the presence of a specific expansion of IgG clonotypes that impart reactivity with disease related autoantigens. The amino acid and nucleotide sequence of autoantibodies derived from human lupus present in immune complexes and renal eluates of subjects with active disease show features of diversification with a high rate of replacement or silent mutations and the clustering of mutations in the hypervariable region. This distinctive feature implies that a pure polyclonal activation cannot be the only mechanism responsible for autoantibody production. An antigen-driven process is more likely to play a role in their generation. It has been suggested that the antibodies may be stimulated by nucleic acid antigens or pathogens. B cells whose paratopes have 
complementary determining regions (CDR) which are formed by amino acids that can promote DNA binding may be selectively stimulated by nucleic acid related structures (31).

A number of studies support the role of free radicals in the initiation and progression of autoimmune response. Therefore, in chronic inflammatory diseases, peroxynitrite generated by phagocytic cells may cause damage to DNA and proteins, generating neoepitopes that lead to the production of antibodies cross-reacting with nDNA or histone proteins. Modification of native DNA or proteins by peroxynitrite might also lead to the generation of neoepitopes on the molecule, and may be one of the factors for the induction of the immune responses as seen in an autoimmune disease like systemic lupus erythematosus (SLE) (58). The peroxynitrite modified human DNA was found to be highly immunogenic in rabbits inducing high titre immunogen specific antibodies (Figure 4). The data demonstrate that the antibodies, though cross-reactive with various nucleic acids and polynucleotides, preferentially bind peroxynitrite-modified epitopes on DNA (58).

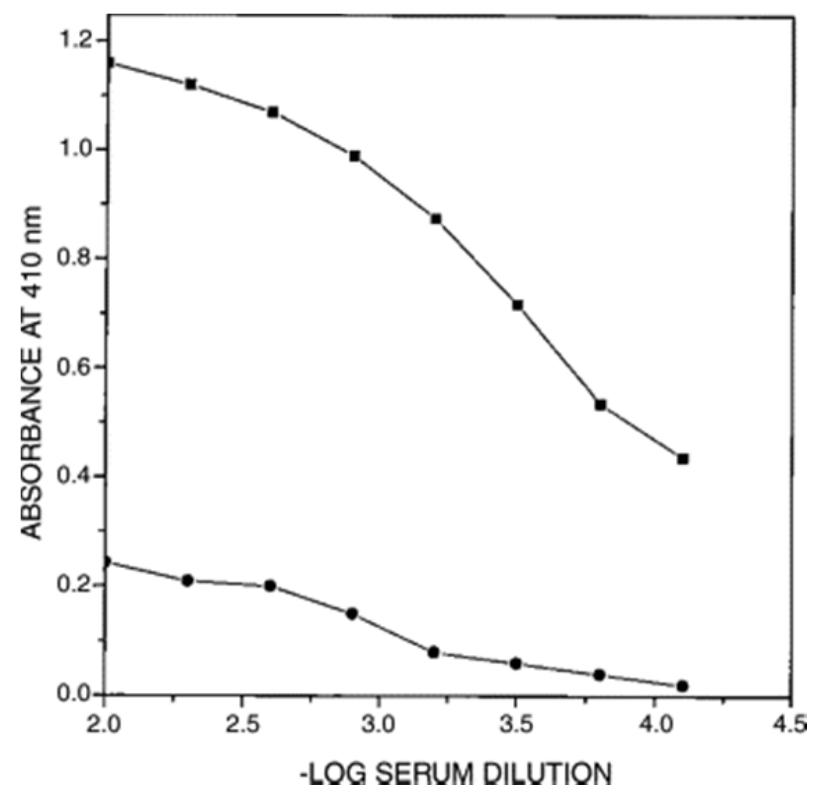

Fig. 4. Antigenicity of peroxynitrite modified human DNA. Direct binding ELISA of antiperoxynitrite-human DNA antisera $(\circ)$ and pre-immune sera $(\bullet)$. The microtitre plates were coated with peroxynitrite modified-human DNA $(2.5 \mu \mathrm{g} / \mathrm{ml})$.

DNA is a non-immunogenic entity, but any significant unrepaired alteration in its basic structure could render it "foreign," leading to the activation of immune pathways. A change in the structure of DNA could either be due to radiation or interaction with different free radicals. NO and its derivatives are among the radicals known to interact with DNA and are primarily involved in deamination of DNA bases. Peroxynitrite, on the other hand, leads to more extensive damage than that caused by an equivalent dose of $\mathrm{NO}$. Formation occurs both intracellularly inside macrophages and extracellularly, and causes DNA strand breaks and modification of guanine (66). The two main products identified from the reaction of deoxyguanosine with peroxynitrite are 8-oxodeoxyguanine and 8-nitroguanine. The former 
has long been regarded as a reliable biomarker for monitoring DNA damage in studies with various oxidizing agents. The peroxynitrite-modified DNA has been shown to acquire immunogenicity and was suspected to be one of the causes for generation of autoantibodies in cancer and autoimmune disorders $(12,67)$. The peroxynitrite modified DNA is a potent immunizing stimulus, inducing high-titer immunogen-specific antibodies in rabbits. Peroxynitrite modification might have generated potential neoepitopes against which antibodies are raised. The analysis of cross-reactivity indicates that anti-peroxynitrite-DNA IgG is immunogen-specific, showing various extents of cross-reactivity attributable to sharing of common antigenic determinants. The common antigenic determinants between peroxynitrite-DNA and nDNA could possibly be the sugar-phosphate backbone, since peroxynitrite attacks DNA and causes single strand breaks through sugar fragmentation. Induced antibodies also recognized synthetic polynucleotides, representing A/B conformations, with a preference for the B-form (12). Elevated levels of $\cdot \mathrm{NO}$ in systemic lupus erythematosus (SLE) patients suggest a role for $\mathrm{NO}$ in the pathogenesis of the disease. Murine models of SLE demonstrate abnormally high levels of $\mathrm{NO}$ compared with normal mice, whereas systemic blockade of $\mathrm{NO}$ production reduces disease activity. Elevated serum nitrate levels correlate with indices of disease activity and, along with serum titers of anti-(ds DNA) antibodies, serve as indicators of SLE (68-69). Auto-antibody production in SLE has been attributed to either selective stimulation of autoreactive Bcells by self-antigens or antigens crossreactive with self. The persistence of anti-DNA antibodies in SLE patients, despite systems to suppress self-recognition, suggests that the response is driven by an antigen resembling nDNA. The DNA damage by peroxynitrite is far more lethal than that caused by $\mathrm{NO}$ alone, leading to the perturbations in nDNA that render it immunogenic. This modified DNA might therefore play a role in the induction of circulating anti-DNA autoantibodies in various autoimmune disorders including SLE $(12,59)$

Histones are small, highly conserved cationic proteins which bind DNA. They are weak immunogen because of their conserved nature. Histones are major constituent of cells' chromatin and remain confined to nucleus. However, after apoptosis they may appear in circulation as nucleosomes. Incidence of autoantibodies against histone H1, H2A, H2B, H3 and $\mathrm{H} 4$ are $60 \%, 53 \%, 48 \%, 36 \%$ and $29.5 \%$ respectively in the sera of SLE patients (70). Histones also act as autoantigens in humorally-mediated paraneoplastic diseases (71). Furthermore, anti-histone antibodies have also been reported in polymyositis / dermatomyositis (72).

As peroxynitrite reaction involves free radical intermediates, it may favor cross-linking and aggregation during nitration. The extent of cross-linking depends on type of reagent used, protein concentration, type of protein and solvent conditions including $\mathrm{pH}$. The exact chemical nature of the cross-linking is disputed but linkage of side chains of tyrosine residue is the common answer. Formation of tyrosyl radical by peroxynitrite and its reaction with another tyrosyl radical (on same or different histone molecule) may generate $\mathrm{O}, \mathrm{O}^{\prime}$ dityrosine covalent cross-links. Peroxynitrite induces an array of modifications in $\mathrm{H} 2 \mathrm{~A}$ structure namely-tyrosine nitration, formation of protein carbonyl, dityrosine and crosslinking. Such gross structural changes might favor polymerization of native epitopes of $\mathrm{H} 2 \mathrm{~A}$ histone into potent immunogenic neo-epitopes. The histone proteins are conserved proteins and act as weak immunogens. However, they show strong immunogenicity after acetylation and alterations in amino acid structure or sequence can generate neo-epitopes on self proteins causing and immune attack. The oxidative and nitrative action of peroxynitrite 
confers additional immunogenicity on H2A histone and probably there is a direct correlation between nitration and immunogenicity. In another words, peroxynityritemodified H2A still has some old epitopes which are scattered among neo-epitopes. Hence, immunization with peroxynityrite-modified $\mathrm{H} 2 \mathrm{~A}$ may produce polyspecific antibodies which can recognize both old and neo-epitopes or altogether there are two types of antibodies, one recognizing nitrated neo-epitopes and other binding exclusively with old epitopes (73).

The mechanism of autoantibody production in diseases such as SLE has not yet been clearly identified. If antigen selection is an important aspect of differentiation, the nature of the stimulating antigen also remains to be determined. The origin of antibodies remains obscure, although modified DNA appears to be a causative factor in RA and SLE. It is possible that the production of autoantibodies may be the result of free radical attack on DNA or histone proteins causing changes at the macromolecule level. It is therefore postulated that in chronic inflammatory diseases, free radicals generated by phagocytic cells may cause damage to DNA and proteins and antibodies to self-antigen are produced. Also, a defect in the control of apoptosis and delayed clearance of apoptotic debris provide sustained interaction between free radicals and macromolecules, generating neoepitopes which subsequently result in autoimmunity and generating polyspecific autoantibodies (73). Sera of animals immunized with native and peroxynitrite-modified histones were tested on polysorp wells coated with respective immunogens (Figure 5). Modification by $100 \mu \mathrm{m}$ peroxynitrite conferred more high immunogenicity on H2A histone (73).

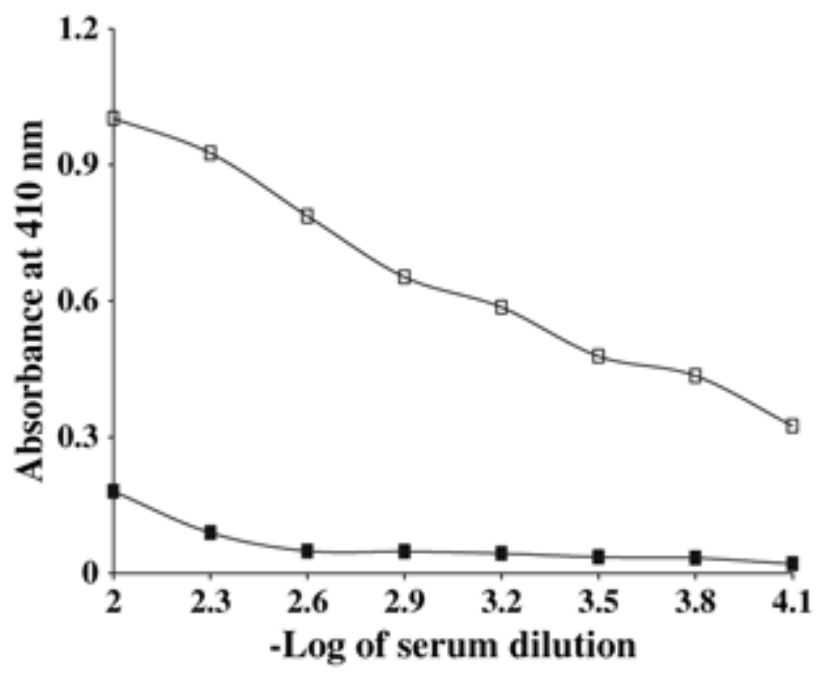

Fig. 5. Antigenicity of peroxynitrite modified proteins. Direct binding ELISA of experimentally induced antibodies against peroxynitrite-modified $\mathrm{H} 2 \mathrm{~A}(\square)$ and native histone $\mathrm{H} 2 \mathrm{~A}(\mathbf{\square})$.

Accumulation of a variety of post-translationally modified self-proteins during inflammation may lead to generation or unmasking of new antigenic epitopes that in turn activate B-and/or T-cells, thereby impairing or bypassing immunological tolerance. Peroxynitrite-modified H2A 
histone could act as an autoantigen leading to generation of anti-H2A histone antibodies. It is envisaged that anti-histone antibodies seen in a sub-group of SLE patients might originate from immunological activity of peroxynitrite-modified histones due to their protection from digestion by normal proteolytic machinery (61). In the context of anti-histone antibodies in drug induced lupus erythematosus, it is quite possible that the drug itself might mimic reaction(s) pathway(s) leading to abnormal synthesis of peroxynitrite. The peroxynitrite may then modify the structure of histone making it immunogenic (76).

Hence, alteration of DNA or proteins resulting from photomodification or peroxynitrite could lead to the development of antibodies or mutations to modified DNA. Therefore, the DNA-lysine photoadduct and modified photoadducts could have important implications in toxicology, carcinogenesis, and autoimmune phenomena. Hence, understanding the pathophysiology of peroxynitrite could lead to important therapeutic interventions against this increasingly important and physiologically relevant reactive nitrogen species.

\section{References}

[1] Szabo C. Multiple pathways of peroxynitrite cytotoxicity. Toxicol Lett. (2003) 140-141: 105-112.

[2] Pacher P, Beckman JS, Liaudet L. Nitric oxide and peroxynitrite in health and disease. Physiol Rev. (2007) 87(1): 315-424.

[3] Szabo C, Ischiropoulos H, Radi R. Peroxynitrite: biochemistry, pathophysiology and development of therapeutics. Nat Rev Drug Discov. (2007) 6(8): 662-80.

[4] Squadrito GL, Pryor WA . Oxidative chemistry of nitric oxide: the roles of superoxide, peroxynitrite, and carbon dioxide. Free Rad Biol Med (1998), 25(4-5):392-403.

[5] Radi R, Peluffo G, Alvarez MN, Naviliat M, Cayota A. Unraveling peroxynitrite formation in biological systems. Free Radic Biol Med. (2001) 30(5): 463-88.

[6] Forstermann U, Munzel T. Endothelial nitric oxide synthase in vascular disease: from marvel to menace. Circulation. (2006) 113(13): 1708-14.

[7] Romero N, Denicola A, Radi R. Red blood cells in the metabolism of nitric oxide-derived peroxynitrite. IUBMB Life. (2006) 58(10): 572-80.

[8] Ahmad R, Rasheed Z Ahsan H. Biochemical and cellular toxicology of peroxynitrite: implications in cell death and autoimmune phenomenon. Immunopharmacology and Immunotoxicology (2009) 18(7): 388-396.

[9] Pryor W A, Squandrito G I. Chemistry of peroxynitrite: aproduct from the reaction of nitrite oxide with superoxide. Am J Physiol. (1995),268, L699-22.

[10] Oshima H,Frisen M, Bruer I, Bartsch H. Nitrotyrosine as a marker for endogenous nitrosation and nitration of proteins. Food Chem Toxicol (1990), 28: 647-52.

[11] Good P F, Hsu A, Werner P, Perl DP, Olanow C W. Protein nitration in Parkinson's disease. J Neuropathol Exp Neurol (1998), 57:338-42.

[12] Browne S E, Ferrante R J , Beal M F. Oxidative stress in Huntington's disease, Brain Pathol. (1999): 147-63

[13] Smith M A, Richey harris P L, Sayre L M, Beckman J S, Perry G. Widespread peroxynitrite-mediated damage in Alzheimer's disease. J Neurosci (1997), 17:2653-7

[14] Bagasra O, Michaelis FH, Zheng YM et al. Activation of the inducible form of nitric oxide synthase in the brains of patients with multiple sclerosis. Proc Natl Acad Sci (USA) (1995), 92: 12041-5 
[15] Bachmaier K, Nikolaus N, Pommerer C et al. iNOS expression and nitrotyrosine formation in the myocardium in response to inflammation is controlled by the interferon transcription factor 1. Circulation (1997), 96:585-91

[16] Oates J C, Christensen E F, Reilly C M, Self S E, Gilkeson G S. Prospective measure of serum 3-nitrotyrosine levels in systemic lupus erythmatosus:correlation with disease activity. Proc Assoc Am Physicians (1995), 111:611-21

[17] Kaur H,Halliwell B. Evidence for nitric oxide mediated oxidative damage in chronic inflammation. Nitrotyrosine in serum and synovial fluid from rheumatoid patients. FEBS Lett (1994),350:9-12

[18] Anderson S M. Post translational modification of self antigens: implications for autoimmunity.Curr Opin Immunol (2004), 16:753-8

[19] Olins A L, Olins D E. Stereo electron microscopy of the 25-nm chromatin fibres in isolated nuclei.J Cell Biol (1979), 81:260-5

[20] Monesteir M, Kortzin B L. Antibodies to histones in systemic lupus erythmatosus and drug-induced lupus syndromes. Rheum Dis Clin North Am (1992), 18: 415-536

[21] Haqqani A S, Kelly J F, Birnboin H C. Selective nitration of histone tyrosine residues in vivo mutatect tumors. J Biol Chem (2002), 277:3614-21

[22] Maeda $H$, Akaike T. Nitric oxide and oxygen radicals in infection, inflammation, and cancer. Biochemistry (Mosc). (1998) 63(7): 854-865.

[23] Ohshima $\mathrm{H}$, Bartsch $\mathrm{H}$. Chronic infections and inflammatory processes as cancer risk factors: possible role of nitric oxide in carcinogenesis. Mutat Res. (1994) 305(2): 253264.

[24] Rubbo H. Nitric oxide and peroxynitrite in lipid peroxidation. Medicina (B Aires). (1998) 58(4), 361-366.

[25] Rubbo H, Freeman BA. Nitric oxide regulation of lipid oxidation reactions: formation and analysis of nitrogen-containing oxidized lipid derivatives. Methods Enzymol. (1996) 269: 385-394.

[26] Rubbo H, Radi R, Trujillo M, Telleri R, Kalyanaraman B, Barnes S, Kirk M, Freeman B A. Nitric oxide regulation of superoxide and peroxynitrite-dependent lipid peroxidation. Formation of novel nitrogen-containing oxidized lipid derivatives. J Biol Chem (1994) 269(42): 26066-26075.

[27] Ramezanian MS, Padmaja S, Koppenol WH. Nitration and hydroxylation of phenolic compounds by Peroxynitrite. Chem Res Toxicol. (1996) 9(1): 232-240.

[28] Ramezanian MS, Padmaja S, Koppenol WH Nitration and hydroxylation of phenolic compounds by Peroxynitrite. Methods Enzymol. (1996) 269: 195-201.

[29] Alvarez B, Radi R. Peroxynitrite reactivity with amino acids and proteins. Amino Acids. (2003) 25(3-4): 295-311.

[30] Luxford C, Morin B, Dean RT, Davies MJ Histone H1 and other protein- and amino acid-hydroperoxides can give rise to free radicals which oxidize DNA. Biochem J. (1999); 344(1), 125-134.

[31] Ahsan H, Ali A, Ali R (2003). Oxygen free radicals and systemic autoimmunity. Clin. Exp. Immunol. 131(3):398-404.

[32] Ahsan H, Abdi S, Ali A (2002) Recognition of DNA-arginine photoadduct by anti-DNA auto-antibodies in systemic lupus erythematosus. Ind. J. Med. Res. 115:201-211. 
[33] Dixit K, Ahsan H, Ali A (2003) Polydeoxyribonucleotide C photoconjugated with lysine or arginine present unique epitopes for human anti-DNA autoantibodies. Hum. Immunol. 64(9): 880-886.

[34] Habib S, Moinuddin, Ali R (2006) Peroxynitrite modified DNA: a better antigen for systemic lupus erythematosus anti-DNA autoantibodies. Biotechnol. Appl. Biochem. 43(2): 65-70.

[35] Szabo C, Ohshima H (1997) DNA damage induced by peroxynitrite: subsequent biological effects. Nitric Oxide 1(7):373-385.

[36] Yermilov V, Rubio J, Becchi M, Friesen MD, Pignatelli B, Ohshima H (1995) Formation of 8-nitroguanine by the reaction of guanine with peroxynitrite in vitro. Carcinogenesis 16(9): 2045-2050.

[37] Douki T, Cadet J. Peroxynitrite mediated oxidation of purine bases of nucleosides and isolated DNA. Free Rad Res. (1996) 24(5): 369-380.

[38] Douki T, Cadet J, Ames BN. An adduct between peroxynitrite and 2'-deoxyguanosine: 4,5-dihydro-5-hydroxy-4-(nitrosooxy)-2'-deoxyguanosine. Chem Res Toxicol. (1996) 9(1): 3-7.

[39] Wiseman H, Halliwell B. Damage to DNA by reactive oxygen and nitrogen species: role in inflammatory disease and progression to cancer. Biochem J. (1996) 313(1): 17-29.

[40] Ohshima H, Virág L, Souza J, Yermilov V, Pignatelli B, Masuda M, Szabo C. Detection of certain peroxynitrite-induced DNA modifications. Methods Mol Biol. (2002) 186: 77-88.

[41] Ohshima H, Virág L, Souza J, Yermilov V, Pignatelli B, Masuda M, Szabo C. Detection of certain peroxynitrite-induced DNA modifications. Methods Mol Biol. (2002) 186: 77-88.

[42] Tretyakova NY, Burney S, Pamir B, Wishnok JS, Dedon PC, Wogan GN, Tannenbaum, SR. Peroxynitrite-induced DNA damage in the sup F gene: correlation with the mutational spectrum. Mutat Res (2000) 447(2): 287-303.

[43] Ames BN, Shigenaga MK, Gold LS. DNA lesions, inducible DNA repair, and cell division: three key factors in mutagenesis and carcinogenesis. Environ Health Perspect. (1993) 101(suppl 5): 35-44.

[44] Ames BN, Shigenaga MK, Hagen TM Oxidants, antioxidants, and the degenerative diseases of aging. Proc Natl Acad Sci (USA) (1993) 90(17): 7915-7922.

[45] Sawa T, Ohshima H. Nitrative DNA damage in inflammation and its possible role in carcinogenesis. Nitric Oxide. (2006) 14(2): 91-100.

[46] Yermilov V, Rubio J, Becchi M, Friesen MD, Pignatelli B, Ohshima H. Formation of 8nitroguanine by the reaction of guanine with peroxynitrite in vitro. Carcinogenesis. (1995) 16(9): 2045-2050.

[47] Ohshima H. Genetic and epigenetic damage induced by reactive nitrogen species: implications in carcinogenesis. Toxicol Lett (2003) 140-141: 99-104.

[48] Suzuki T, Mower HF, Friesen MD, Gilibert I, Sawa T, Ohshima, H. Nitration and nitrosation of $\mathrm{N}$-acetyl-L-tryptophan and tryptophan residues in proteins by various reactive nitrogen species. Free Rad Biol Med. (2004) 37(5): 671-681.

[49] Beckman JS, Koppenol WH. Nitric oxide, superoxide, and peroxynitrite: the good, the bad, and ugly. Am J Physiol. (1996) 271(5 Pt 1): C1424-1437. 
[50] Beckman JS. Oxidative damage and tyrosine nitration from Peroxynitrite. Chem Res Toxicol. (1996) 9(5): 836-844.

[51] Beckman JS. Protein tyrosine nitration and peroxynitrite. FASEB J. (2002) 16(9): 1144.

[52] Greenacre SA, Ischiropoulos H. Tyrosine nitration: localisation, quantification, consequences for protein function and signal transduction. Free Rad Res. (2001) 34(6): 541-581.

[53] Ischiropoulos $\mathrm{H}$, Zhu L, Chen J, Tsai M, Martin JC, Smith CD, Beckman JS. Peroxynitrite-mediated tyrosine nitration catalyzed by superoxide dismutase. Arch Biochem Biophy. (1992) 298(2): 431-437.

[54] Hausladen A, Fridovich I. Superoxide and peroxynitrite inactivate aconitases, but nitric oxide does not. J Biol Chem. (1994) 269(47): 29405-29408.

[55] Mihm MJ, Yu F, Carnes CA, Reiser PJ, McCarthy PM, Van Wagoner DR, Bauer JA Impaired myofibrillar energetics and oxidative injury during human atrial fibrillation. Circulation. (2001) 104(2): 174-180.

[56] Grune T, Blasig IE, Sitte N, Roloff B, Haseloff R, Davies KJ. Peroxynitrite increases the degradation of aconitase and other cellular proteins by proteasome. J Biol Chem. (1998) 273(18): 10857-10862.

[57] Islam N, Ali R. (1998) Immunological studies on DNA-lysine photoadduct. Biochem. Mol. Biol. Int. 45(3):453-464.

[58] Dixit K, Moinuddin, Ali A (2005) Immunological studies on peroxynitrite modified DNA. Life Sci. 77(21):2626-2642.

[59] Ahmad R, Rasheed Z, Kaushal E, Singh D, Ahsan H. Biochemical evaluation of human DNA-lysine photoadduct treated with peroxynitrite. Toxicol Mech Meth. (2008) 18(7): 589-595.

[60] Gong C X, Liu F, Grundke-Iqbal I, Iqbal K.Dysregulation of protein phosphorylation/dephosphorylation in Alzheimer's disease: atherapeutic target.J Biomed Biotechnol (2006), 2006:31825.

[61] Ahmad R, Alam K, Ali R. Antigen binding characteristics of antibodies against hydroxyl radical modified thymidine monophosphate. Immunol Lett (2000),71:111115

[62] Pisetsky DS. Antinuclear antibodies. Diagn Lab Immunol (1994),14:371-85

[63] Isenberg D, Shenfeld Y.The origin and significance of anti-DNA antibodies.Immunol Today (1997),8:279-81

[64] Tan EM. Autoantibody to nuclear antigens (ANA):their immunobiology and medicine. Adv Immunol (1982),33:167-208

[65] Pollard KM, Jones JE, TanEM, Theofilopoulos AN, Dixon FJ, Rubin RL. Polynucleotide specificity of murine monoclonal anti-DNA antibodies. Clin Immunol Immunopathol (1986), 40:197-208.

[66] Burney S, Caulfield JL, Niles JC, Wishnok JS, Tannenbaum SR. The chemistry of DNA damage from nitric oxide and peroxynitrite. Mutat Res (1999),424 (1-2):37-49.

[67] Habib S, Moinuddin, Ali R. Acquired antigenicity of DNA after modification with peroxynitrite. Int J Biol macromol (2005),35(3-4):221-225.

[68] Wanchu A, Khullar M, Deodhar SD bambery P, Sud A. Nitric oxide synthesis is increased in patients with systemic lupus erythmatosus. Rheumatol Int. (1998),18(2):41-43. 
[69] Oates JC, Ruiz P, Alexander A, Pippen AM, Gilkeson GS. Effect of late modulation of nitric oxide production on murine lupus. Clin Immunol Immunopathol. (1997), 83(1):86-92.

[70] Gheidira I, Andolsi H, Mankai A, Fabien N, Jeddi M. Anti-histone antibodies in systemic lupus erythmatosus, comparison of three assays:ELISA, dot blot and immunoblot. Pathol Biol (2006), 54: 148-54

[71] Marc M, Thomas M, Lothar B, Frank SL. Anti-histone antibodies in subacute sensory neuropathy. J Neurooncol (1991),11:71-75.

[72] Masahidi K, Hironobu I, Norhito Y, Shinichi S, Kanako K, Kunihiko T. Prevelance and antigen specificity of anti-histone antibodies in patients with polymyositis/ dermatomyositis. J Invest Dermatol (1999), 112:1523-747.

[73] Khan MA, Dixit K, Jabeen S, Moinuddin, Alam K. Impact of peroxynitrite modification on structure and immunogenicity of H2A histone. Scan J Immunol (2008), 69:99109. 


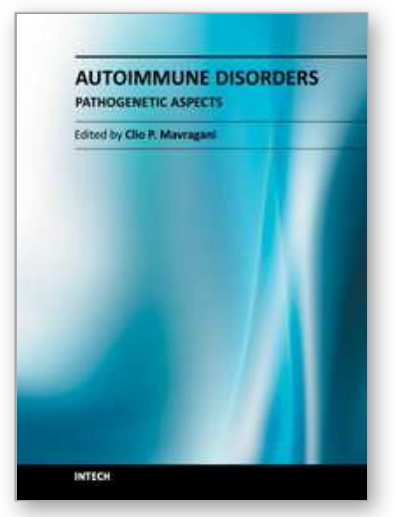

\author{
Autoimmune Disorders - Pathogenetic Aspects \\ Edited by Dr. Clio Mavragani
}

ISBN 978-953-307-643-0

Hard cover, 508 pages

Publisher InTech

Published online 26, October, 2011

Published in print edition October, 2011

The present edition entitled "Autoimmune disorders - Pathogenetic aspects" aims to present the current available evidence of etiopathogenetic insights of both systemic and organ specific autoimmune disorders, the crossover interactions among autoimmunity, cardiovascular morbidity and malignancy as well as novel findings in the exciting fields of osteoimmunology and immunology of pregnancy.

\title{
How to reference
}

In order to correctly reference this scholarly work, feel free to copy and paste the following:

Rizwan Ahmad and Haseeb Ahsan (2011). Contribution of Peroxynitrite, a Reactive Nitrogen Species, in the Pathogenesis of Autoimmunity, Autoimmune Disorders - Pathogenetic Aspects, Dr. Clio Mavragani (Ed.), ISBN: 978-953-307-643-0, InTech, Available from: http://www.intechopen.com/books/autoimmune-disorderspathogenetic-aspects/contribution-of-peroxynitrite-a-reactive-nitrogen-species-in-the-pathogenesis-ofautoimmunity

\section{INTECH}

open science | open minds

\author{
InTech Europe \\ University Campus STeP Ri \\ Slavka Krautzeka 83/A \\ 51000 Rijeka, Croatia \\ Phone: +385 (51) 770447 \\ Fax: +385 (51) 686166 \\ www.intechopen.com
}

\author{
InTech China \\ Unit 405, Office Block, Hotel Equatorial Shanghai \\ No.65, Yan An Road (West), Shanghai, 200040, China \\ 中国上海市延安西路65号上海国际贵都大饭店办公楼 405 单元 \\ Phone: +86-21-62489820 \\ Fax: $+86-21-62489821$
}


(C) 2011 The Author(s). Licensee IntechOpen. This is an open access article distributed under the terms of the Creative Commons Attribution 3.0 License, which permits unrestricted use, distribution, and reproduction in any medium, provided the original work is properly cited. 